\section{Case Reports in Neurology}

Case Rep Neurol 2021;13:46-49

DOI: 10.1159/000511955

Published online: January 27, 2021

(C) 2021 The Author(s)

Published by S. Karger AG, Basel

www.karger.com/crn

This article is licensed under the Creative Commons Attribution-NonCommercial 4.0 International License (CC BY-NC) (http://www.karger.com/Services/OpenAccessLicense).

Usage and distribution for commercial purposes requires written permission.

\title{
Luxury Perfusion Producing Sensory Aphasia
}

\author{
Daiki Sakai Ryuji Sakakibara Fuyuki Tateno Yosuke Aiba \\ Neurology, Internal Medicine, Sakura Medical Center, Toho University, Sakura, Japan
}

\section{Keywords}

Luxury perfusion $\cdot$ Reperfusion brain injury $\cdot$ Stroke $\cdot$ Sensory aphasia

\begin{abstract}
We describe the case of an 86-year-old Japanese man who, by luxury perfusion after spontaneous recanalization of the left middle cerebral artery/internal carotid artery, produced acute transient sensory aphasia. This rare phenomenon is thought to be caused by reperfusion brain injury.

(C) 2021 The Author(s)

Published by S. Karger AG, Basel
\end{abstract}

\section{Introduction}

Luxury perfusion has been regarded a rather plausible phenomenon after spontaneous or endovascular intervention-induced recanalization of ischemic stroke. It has recently been recognized that neurological deterioration might also occur by reperfusion brain injury after carotid endarterectomy $[1,2]$. In contrast, in acute ischemic stroke, this phenomenon has been rarely described thus far. We recently had a case of such a man in whom acute transient sensory aphasia was the presenting symptom. 


\section{Case Reports in Neurology}

Case Rep Neurol 2021;13:46-49

\begin{tabular}{l|l}
\hline DOI: 10.1159/000511955 & ๑ 2021 The Author(s). Published by S. Karger AG, Basel
\end{tabular} www.karger.com/crn

Sakai et al.: Luxury Perfusion Producing Sensory Aphasia

\section{Case Report}

An 86-year-old Japanese man was referred to us because of sudden onset of sensory aphasia but without right hemiplegia. He had no seizure. 3T magnetic resonance angiography on admission showed severe stenosis in the left internal carotid artery, suggesting that his left internal carotid artery or left middle cerebral artery had once occluded and recanalized spontaneously. Diffusion-weighted magnetic resonance images showed three punctate ischemic lesions in the left middle-posterior hemisphere (posterior half of the left middle cerebral artery area); they were regarded not large enough to produce clinical symptoms in the patient. In contrast, in the left middle-posterior hemisphere, brain perfusion scan by ECD-SPECT was able to reveal luxury perfusion (Fig. 1), which might have produced his sensory aphasia. Two weeks later, his sensory aphasia had resolved completely, without any progression of his ischemic lesions.

\section{Discussion}

Reperfusion brain injury (luxury perfusion) after carotid endarterectomy is recently being recognized as an unwanted, hazardous neurological deficit $[1,2]$. The most important risk factors in reperfusion brain injury are diminished cerebrovascular reserve, postmaneuver hypertension, and hyperperfusion lasting more than several hours after carotid endarterectomy [3]. Impaired autoregulation as a result of endothelial dysfunction mediated by generation of free oxygen radicals is implicated in the pathogenesis of reperfusion brain injury [3]. Although such a phenomenon has been rarely described in acute ischemic stroke, our patient produced acute sensory aphasia along with luxury perfusion in the left middle cerebral artery area, but without marked oligemia/infarction in the same area.

In conclusion, this case report highlights the possibility that spontaneous recanalization in acute ischemic stroke causes luxury perfusion that underlies clinical neurological deficit, a mechanism similar to endarterectomy cases.

\section{Statement of Ethics}

The subject provided written informed consent to publication of his case (including publication of images). The study concept was in accordance with the Declaration of Helsinki principles and was approved by the local ethics committee.

\section{Conflict of Interest Statement}

The authors have no conflict of interest to disclose.

\section{Funding Sources}

No targeted funding is reported.

\section{Karger'}




\section{Case Reports in Neurology}

\begin{tabular}{l|l}
\hline DOI: 10.1159/000511955 & $\begin{array}{l}\text { (c) } 2021 \text { The Author(s). Published by S. Karger AG, Basel } \\
\text { www.karger.com/crn }\end{array}$ \\
\hline \multicolumn{2}{|l}{ Sakai et al: Luxury Perfusion Producing Sensory Aphasia }
\end{tabular}

Sakai et al.: Luxury Perfusion Producing Sensory Aphasia

\section{Author Contributions}

D. Sakai participated in the acquisition, analysis, and interpretation of data. R. Sakakibara participated in the study concept and design, acquisition of data, analysis and interpretation of data, and preparation of the manuscript. F. Tateno participated in the acquisition of data. Y. Aiba participated in the acquisition of data.

\section{References}

1 Aceto P, Lai C, De Crescenzo F, Crea MA, Di Franco V, Pellicano GR, et al. Cognitive decline after carotid endarterectomy: systematic review and meta-analysis. Eur J Anaesthesiol. 2020 Nov;37(11):1066-74.

2 Shimonaga K, Matsushige T, Hosogai M, Hashimoto Y, Mizoue T, Ono C, et al. Hyperperfusion after endovascular reperfusion therapy for acute ischemic stroke. J Stroke Cerebrovasc Dis. 2019 May;28(5): 1212-8.

3 van Mook WN, Rennenberg RJ, Schurink GW, van Oostenbrugge RJ, Mess WH, Hofman PA, et al. Cerebral hyperperfusion syndrome. Lancet Neurol. 2005 Dec;4(12):877-88. 
Case Reports in Neurology
Case Rep Neurol 2021;13:46-49

DOI: $10.1159 / 000511955$

(c) 2021 The Author(s). Published by S. Karger AG, Basel www.karger.com/crn

Sakai et al.: Luxury Perfusion Producing Sensory Aphasia

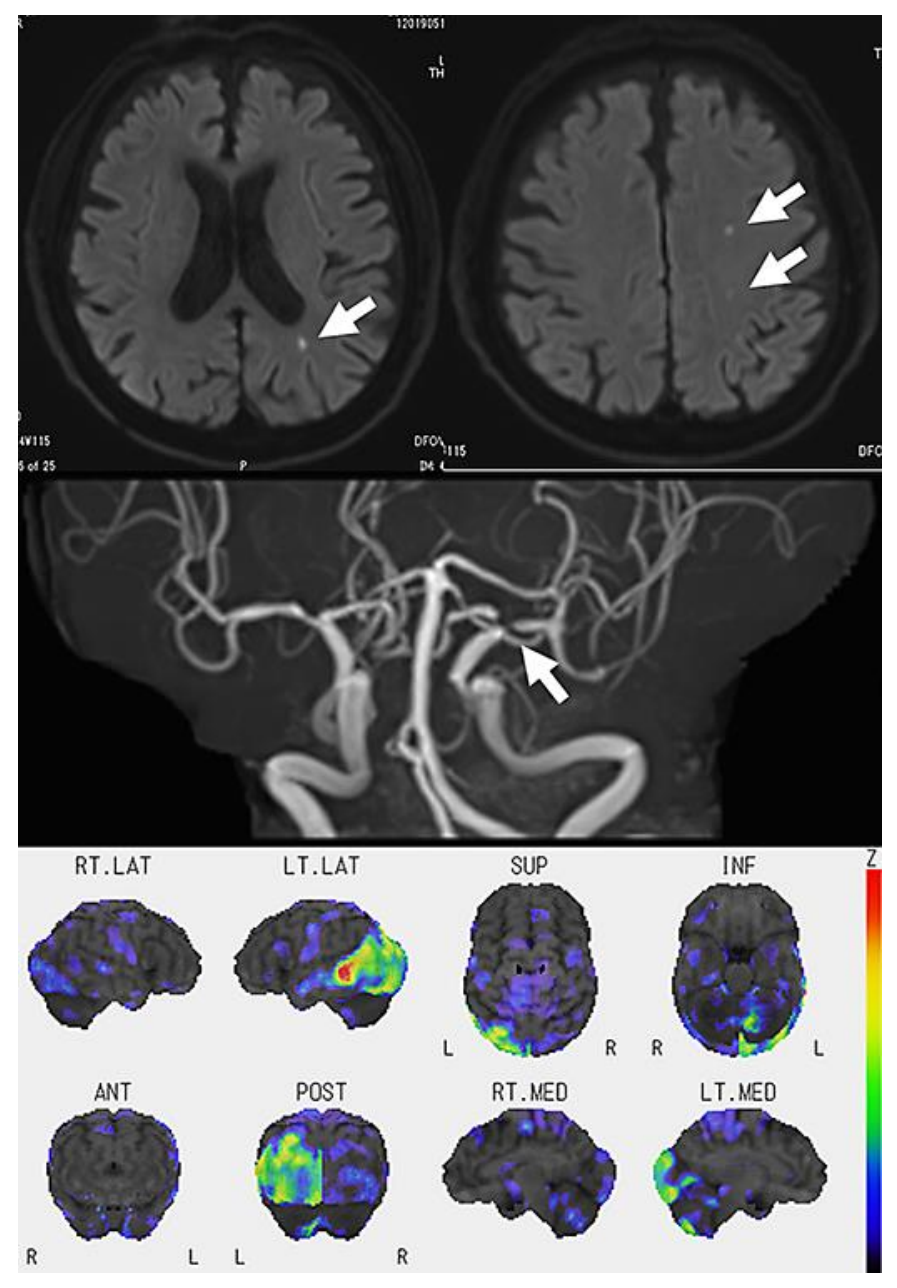

Fig. 1. Brain imaging of the patient. Upper panel: diffusion-weighted magnetic resonance images. Middle panel: magnetic resonance angiography. Lower panel: brain perfusion scan by ECD-SPECT, showing statistically significant luxury perfusion in the left middle-posterior hemisphere. 